\title{
Analysis of Teachers' Commitment and Dimensions of Organizational Commitment in Edo State Public Secondary Schools
}

\author{
Victor F. Peretomode \\ Lecturer, Department of Educational, \\ Management and Foundations, \\ Delta State University, Abraka, Nigeria \\ Stella O. Bello \\ Teacher, Ogbe Secondary School, \\ Benin City, Edo State, Nigeria
}

\section{Doi: 10.2478/jesr-2018-0034}

\begin{abstract}
The study investigates the level of teachers' overall commitment and the level of commitment in each of the three dimensions of organizational commitment. This study which adopts the ex-post facto research design uses descriptive statistics to analyze the data. The findings reveal that the overall level of teachers' commitment to official duties is very high and also high across each of the three dimensions of organizational commitment. It, however, recommends that government should provide funds for training and retraining of teachers so as to meet the challenges of the on-going economic and social reforms in this time of dwindling State and national resources in order to sustain and possibly improve upon this high level of commitment among the teachers to their duties and to the schools.
\end{abstract}

Keywords: Teachers commitment, normative, affective and continuance, Secondary Schools

\section{Introduction}

In any modern nation, the educational system is often considered as one of the most important social institutions for socio-economic, technological and scientific development. In this twenty first century characterized by knowledge explosion and where knowledge economy rules the world, the place of quality education at all levels cannot be overemphazied and teachers are the most critical resource in schools.

In Nigeria, the challenge to the educational system in the recent times has to do with the provision of quality education now and for future generations in the light of the down turn in the mono-economy and the nation's reliance on crude oil export. In order to prepare students with sufficient knowledge, attitude and skills to face the rapidly changing world as well as to fulfill the aspiration of nation building, the relevance of teachers, their quality, commitment, morale, attitude, and the school environment in which learning takes place are very significant. The National Policy on Education of Nigeria (NPE 2014) recognizes that the quality of education and its products cannot rise above the quality of its teachers.

Teachers are generally considered as the most important resource in the education sector. An important variable in teacher quality in schools is teacher commitment. For instance, Australian Association of Education (AARE, 2004) recognized that the degree to which teachers have to "commit themselves to their schools, students, teaching activities, profession, colleagues and the 
society are very crucial (Karluki et al, 2014).

The concept of commitment is the subject of interest in many organizations because it refers not only to the level of investment in an organization but also signifies the strength of bound between an employee and an organization. This in turn reflects the degree to which an employee has internalized and adapted the characteristics and perspectives of the organization (Yukl, 2006; Morrow, 1993; Oreilly and Chatman, 1986; Buchanan, 1974).

There are several benefits accruable to an organization where commitment is dominant. These include teamwork, job satisfaction, participative decision making, openness, dedication to duty, responsible and high productive workers, decrease in employee turnover, decreased disagreements and conflicts and unexcused stay away from work among employees; among others (Asurakutlu, 2007; Bayukdere and Solmus, 2006 and Benkhoff, 1997). And Porter, Steers, Mowday and Boulian (1974) characterized organizational commitment by three factors namely the desire to remain in an organization, willingness to exert considerable efforts on its behalf and belief in and acceptance of its goals and values.

However, Meyer and Allen (1991), based on observations from several findings and types of organizations in 1990, developed a multidimensional model of commitment comprising three components namely affective, continuance and normative. Affective commitment (AC) has been defined as an employees emotional attachment to, identification with and involvement in the organization. Continuance commitment (CC), on the other hand, has to do with one's awareness of the material and psychological costs associated with leaving the present organization. The third component which is normative commitment has to do with an employee's ideology or a sense or feeling of obligations towards the organization and the individuals moral belief that it is right and moral to continue within the organization. For example, the school or the State may have granted scholarship to a teacher to undertake a training programme for which he had signed a bond to the school for certain number of years and he would not like to violate terms of the bond.

The three components of the Meyer and Allen (1997) have been represented pictorially in Figure 1.

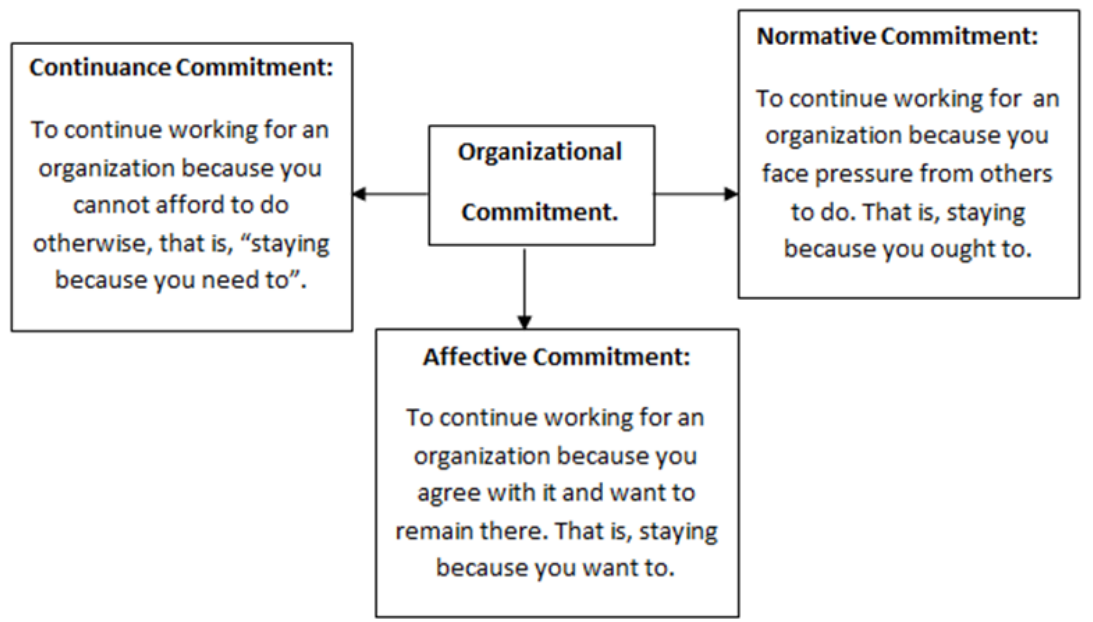

Figure 1: Pictorial Presentation of the Three Types of Organizational Commitment

Source: Meyer, J.P and Allen, N.J (1 997). Commitment in the workplace: Theory, Research and Application. Thousandoaks, CA: SAGE Publications

\section{Statement of Problem}

Research findings have shown that organizational commitment can be a major determinant of organizational performance or effectiveness (Riketta, 2002) and Dannetta (2002) have found that 
committed teachers are dedicated to helping students learn regardless of academic difficulties or social background. It has also been established that once an employee has a true commitment it is hard to give up on the values that he believes in, in the organization.

In recent times, teachers' strike, students threats, violence, insecurity to life and property, underfunding, lack of facilities and the effects of the economic downturn have all conspired to make teaching in schools unpalatable and difficult in Nigeria. These problems are increasingly being recognized as serious issues that could pose challenges to teachers' level of commitment and the quality of education in States in Nigeria.

\section{Purpose of Study}

The purpose of this short study was to examine the level of teachers overall commitment and the level of their commitment in each of the three dimensions of' organizational commitment in Edo State of Nigeria.

\section{Research Questions}

The paper was set up to answer two research questions:

1) What is the level of teachers' overall commitment to their duties in Edo State public Secondary School?

2) What is the level of teachers' commitment in each of the three dimensions of organizational commitment?

\section{Methodology}

This is a descriptive study based on the ex-post factor design. The population comprised all 4568 teachers in the 587 public Secondary Schools in the three Senatorial districts of Edo State. On the basis of proportional stratified random sampling technique, fifty nine (59) schools were selected from among 587 schools in the State and 475 teachers were randomly selected from the 59 public Secondary Schools to constitute the sample for the study. But 457 usable questionnaires representing $96 \%$ were actually used for the study.

A modified Standardized commitment questionnaire titled, "Teachers Commitment (TCSS)" with a test-retest reliability coefficient of 0.79 using Spearman Brown Prophecy $(r)$ was used to collect data from the respondents. The data was analyzed using simple descriptive statistics, frequency, mean and standard deviation.

\section{Results}

The findings were analyzed and presented according to the research questions.

Research Question 1: What is the level of teachers' commitment to their duties and school organization?

To answer this question, the descriptive statistics of mean and standard deviation were applied to the data related to the variable, teachers' commitment. A summary of the analysis is presented in Table 1. A mean score of 2.50 and above is considered high while a mean $(\bar{X})$ less than 2.50 is considered to be low.

Table 1: Level of Teachers' Commitment in Edo State Public Schools

\begin{tabular}{|l|c|c|c|c|c|c|}
\hline Teachers' Commitment & N & M & F & Total Score & $\begin{array}{c}\text { Mean } \\
\bar{X}\end{array}$ & $\begin{array}{c}\text { Standard Deviation } \\
\text { (sd) }\end{array}$ \\
\hline & 457 & 200 & 257 & 1515 & 3.31 & 0.303 \\
\hline
\end{tabular}

From the data in Table 1, the mean score of 3.31 was obtained and this showed that the overall level of teachers' commitment in Edo State public schools was high. On a four point scale this could 
be considered as a very high level of teachers' commitment, that is approximately $84 \%$. It is interesting to note that while the commitment level of both male and female teachers is high, that of the female teachers (3.56) was higher than that of their male counterparts (3.06).

Research Question Two: What is the level of teachers' commitment in each of the three dimensions of organizational commitment?

To answer this research question, the descriptive statistics, mean and standard deviation were applied to the data related to the variable, teachers' organisational commitment. A summary of the analysis is presented in Table 2.

Table 2: Level of Teachers' Commitment in each of the Three Dimensions of Organisational Commitment

\begin{tabular}{|l|l|c|c|c|c|c|}
\hline Variable & Organizational Commitment & $\mathbf{N}$ & Total Score & Mean & $\%$ & Standard Deviation \\
\hline \multirow{3}{*}{ Teachers' Commitment } & Affective & 180 & 640 & 3.55 & 89 & 2.76 \\
\cline { 2 - 7 } & Continuance & 200 & 620 & 3.1 & 78 & 1.13 \\
\cline { 2 - 7 } & Normative & 77 & 212 & 2.75 & 69 & 2.35 \\
\hline
\end{tabular}

From the analysis in Table 2, the mean score of the affective organisational commitment is 3.55 ; that of continuance commitment is 3.1 and that of the normative is 2.75 . Therefore, the level of teacher's commitment in each of the three dimensions of organisaional commitment is high. This implies that teachers' commitment is high across the three dimensions of organisational commitment with affective commitment having the highest mean of 3.55 , followed by continuance commitment with a mean of 3.1 and normative commitment, the lowest, with a mean of 2.75 .

\section{Discussion}

The study examined teachers' overall commitment to duties and their level of commitment in each of the three components of organizational commitment among teachers in Edo State public secondary schools. The study found that the overall level of teachers commitment to the School organization is very high and that of female teachers was higher than that of the male teachers. The inference from this is that the teachers are doing what they were employed to do. This may be due to threat of sanctions against erring teachers if they fail to perform their duties or absent themselves from school and the possible loss of job. This finding is a confirmation of Mutcher's (2005) study which stated that highly committed teachers are dedicated in making a difference; they show willingness to devote personal time outside the classroom and develop quality relationship while managing the work of teaching. The findings of Odor (1975) had shown that no matter the availability of educational infrastructure in the school system, they mean nothing if there are no committed teachers in the public schools. To ensure the successful operation of the school system, committed teachers are needed for schools to perform effectively.

The study also revealed that teachers' commitment to school organization is high across the three dimensions of organizational commitment. This finding is in agreement with those by Kushman (1992), Riehl and Sipple (1996) and Mowday, Steers and Porter (1979). In Edo State, this implies that the teachers are committed because they want to stay in the education system, or have to or ought to because of emotional and psychological attachment to helping students learn. In addition, it could be due to the fear of losing social and economic benefits and / or because of moral obligation to remain within the school system because government might have contributed toward the training of many of these teachers. Finally, their commitment could be attributed to their wiliness and enthusiasm to continue to work in the school system rather than quit for another job at the slightest opportunity (Hulexen, 2009).

Some of the benefits of high committed teachers would include their willingness to do extra work without pay after school hours, punctuality to school and to their classes and other duties (Karluki et al, 2014: 1594) and low attrition rate. 


\section{Conclusion}

The study revealed that teachers in Edo State were highly committed to their work and their commitment is across the three components of organizational commitment. With this high level of commitment among teachers, individual teachers in Edo State would more likely identify with the school and subject matter (Day, 2000), show more desire to carry out the goals of teaching, willing to take on the tasks assigned and to acquire knowledge necessary to do the Job (Good, 2010). According to Nwosu (2012), such committed teachers were likely also to develop sustained energy and efforts. Malik and Rami (2013) have also opined that commitment may also be a basic source of motivation. Thus, Edo State Schools were most likely to benefit from teachers' commitment.

Teachers' commitment to efficiency, productivity and effectiveness in teaching and learning would translate into better school examination results and higher pass rates for learners. It can be concluded that schools which seek to retain their teachers by building strong organizational commitment are in a better position to reap the benefits of a more dedicated, motivated, punctual and reliable teaching staff (Karluki and others, 2014).

Based on the findings, it was recommended that administrators and policy makers alike should seek a plan for modalities of making teaching a more attractive career choice to produce sustainable school improvement and continuous teacher commitment. It is also important for stakeholders to know the aspect of the dimension that play an important role in boosting the commitment of teachers. Until this is done, their present commitment level may not be improved upon or sustained. The teachers should be promoted as at when due and subject them to training and retraining in light of knowledge explosion as the world has become a global village with smart technologies, social media and the internet. This may serve as incentive to aspiring teachers.

\section{References}

AARE (2004) "Teacher Commitment and Engagement: The Dimensions of Idology and Practice associated with Teacher Commitment and Engagement within Australian Perspective; (online:http://www.aare.edu.au/02pap/croo2522.html)

Achimugu, L. (2005). The Agonies of Nigerian Teachers. Ibadan Nigeria: Heinernann Educational Books (Nigeria) Plc.

Ackerman, T., Heafner, T. \& Bartz, D. (2006, April 10). An examination of the relationship between teacher quality and student achievement. (Paper presented at the 2006 annual meeting of America "Educational Research Association, San Francisco, CA).

Asurakutlu, T. (2007). "Trust, Culture and Organizational Reflection". In Managerial Organizational Behavior in Culture, Context. Erdem, R. and C. S. Cukur (eds). Turkish Psychological Association Publishing.

Benkhoff, B. (1997). "Disentangling Organizational Commitment". Personnel Review, 26.

Buchanan, B. (1974). "Building Organizational Commitment: The Socialization of Managers in Work Organizations”. Administrative Science Quarterly'. 19.

Buyukdere, B.\& Solmus, T. (2006). Interpersonal Trust in a Work and a Life. htt://www. sguc. org.

Dannetta, V. (2002). "What Factors Influence a Teacher's Commitment to Student Learning?" Leadership and Policy in Schools, 1(2), 144-171.

Hall, D., Schneider, B. \& Nygren, H. (1970). "Personal factors in Organizational Identification". "Administrative Science Quarterly, 15, 176-190.

Karluki, K.A, Ndirangu, M. Song, K.A. and Oako, M.E. (2014). "Secondary School Teachers' Perceptions of the Factors that Influence their Morale and Commitment to work: A Case of Nakuru District. "International Journal of Innovation and Applied Studies, 9 (4 December): 1589 - 1597)

Kushman, J.W. (1992). "The Organizational Dynamics of Teacher Workplace Commitment: A Study of Urban Elementary and Middle Schools". Educational Administrative Quarterly, 28, 1:5-42.

Meyer J.P. \& Allen, N.J. (1991). "A Three Component Conceptualization of Organizational Commitment". Human Resource Management Review, 1(1), 61-89.

Meyer, J.P. \& Allen, N.J. (1997). Commitment in the Workplace: Theory, Research, and Application. Thousand Oaks, CA: SAGE Publications

Mosadeghrad, A.M. Perlie, E. \& Rosenberg, D. (2011). "A Study of Relationship between Job Stress, Quality of Working Life and Turnover intention among Hospital Employees". Health Services Management Research Journal, 24(4): 170-18 1. 
Mowday, R., Porter, L, W \& Steer, R.M (1982). Organizational Linkage: The Psychology of Commitment, Absenteeism and Turnover. New York: Academic Press.

Mowday, R.T., Steers, R.M., \& Porter L.W. (1979). "The Measurement of Organizational Commitment" Journal of Vocational Behavior, 14, 224-247.

Porter, L.W., Steers, R.M., Mowday, R.T. \& Boulain, P.V. (1974). "Organizational Commitment, Job Satisfaction, and Turnover among Psychiatric Technicians" Journal of Applied Psychology, 59: 240-253.

Riehl, C. \& Sipple, J.W. (1996). "Making the most of Time and Talent: Secondary School Organizational Climates, Teaching Task Environments, and Teacher Commitment" American Educational Research Journal, 33(4): 873 - 901

Riketta, M. (2002). "Attitudinal Organizational Commitment and Job Performance: A Meta- Analysis" Journal of Organizational Behavior, 23, 443-455.

Rosenholtz, S.J. (1989). "Workplace Conditions that Affect Teacher Quality and Commitment: Implications for Teacher Induction Programs" The Elementary School Journal, 89, 421 -439.

Stan, M.M. (2009) Professional Commitment in Teachers: Comparative Study. Pitest: Faculty of Educational Science, University of Pitest.

Tarter, J.C. \& Hoy, W.K. (2004). "A Systems Approach to Quality in Elementary Schools” Journal of Educational Administration, 42(5).

Yukl, G. A. (2010). Leadership in Organizations ( $7^{\text {th }}$ ed.). Upper Saddle River, NJ: Prentice Hall. 